\title{
The Genetic Basis of Primary Myelofibrosis and Its Clinical Relevance
}

\author{
Elisa Rumi ${ }^{1,2, *} \mathbb{0}$, Chiara Trotti $^{1}$, Daniele Vanni ${ }^{1}$, Ilaria Carola Casetti ${ }^{1,2}$, Daniela Pietra ${ }^{2}$ \\ and Emanuela Sant'Antonio ${ }^{3}$ \\ 1 Department of Molecular Medicine, University of Pavia, 27100 Pavia, Italy; \\ chiara.trotti01@universitadipavia.it (C.T.); daniele.vanni01@universitadipavia.it (D.V.); \\ ilaria1985@hotmail.com (I.C.C.) \\ 2 Hematology, Fondazione IRCCS Policlinico San Matteo, 27100 Pavia, Italy; d.pietra@smatteo.pv.it \\ 3 Hematology, Azienda USL Toscana Nord Ovest, 55100 Lucca, Italy; santantonioemanuela@gmail.com \\ * Correspondence: elisarumi@hotmail.com
}

Received: 4 November 2020; Accepted: 23 November 2020; Published: 24 November 2020

\begin{abstract}
Among classical $B C R-A B L$-negative myeloproliferative neoplasms (MPN), primary myelofibrosis (PMF) is the most aggressive subtype from a clinical standpoint, posing a great challenge to clinicians. Whilst the biological consequences of the three MPN driver gene mutations (JAK2, CALR, and MPL) have been well described, recent data has shed light on the complex and dynamic structure of PMF, that involves competing disease subclones, sequentially acquired genomic events, mostly in genes that are recurrently mutated in several myeloid neoplasms and in clonal hematopoiesis, and biological interactions between clonal hematopoietic stem cells and abnormal bone marrow niches. These observations may contribute to explain the wide heterogeneity in patients' clinical presentation and prognosis, and support the recent effort to include molecular information in prognostic scoring systems used for therapeutic decision-making, leading to promising clinical translation. In this review, we aim to address the topic of PMF molecular genetics, focusing on four questions: (1) what is the role of mutations on disease pathogenesis? (2) what is their impact on patients' clinical phenotype? (3) how do we integrate gene mutations in the risk stratification process? (4) how do we take advantage of molecular genetics when it comes to treatment decisions?
\end{abstract}

Keywords: myelofibrosis; myeloproliferative; mutation

\section{Mutation and Disease Pathogenesis}

The so-called "phenotypic driver mutations", which are those able to drive the myeloproliferative phenotype in PMF, occur in JAK2, CALR, or MPL genes. These mutations were initially described as mutually exclusive, but can indeed coexist in a small proportion of cases [1]. Evidence that mutations in JAK2, CALR, or MPL are sufficient to engender an MPN phenotype has been provided by mouse models, where expression of each mutation alone accurately re-capitulate distinctive features of human disease [2-5].

In 2005, a single point mutation (V617F) was identified in half of patients with PMF [6-9]. JAK2 is intimately associated with the cytoplasmic portions of receptors for key hematopoietic cytokines, such as erythropoietin (EPO), thrombopoietin (TPO), and granulocyte colony-stimulating-factor (GCSF). Cytokine receptors are activated by ligand binding, the JAK proteins consequently transphosphorylate one another, which attracts STAT proteins, that are, in turn, phosphorylated by the JAKs. The STATs dimerize and translocate to the nucleus, where they function as a transcription factor to modulate the expression of key genes that regulate proliferation, differentiation, or survival. Normal JAK2 functions to activate intracellular signaling pathways following ligand binding; however, JAK2 V617F is rendered 
constitutively active. Indeed, the mutation results in loss of the normal inhibitory function provided by the pseudokinase $(\mathrm{JH} 2)$ domain upon the active $(\mathrm{JH} 1)$ kinase domain and causes subsequent cytokine independent cell growth.

In 2006, additional genetic aberrations that perturb JAK/STAT signaling were found in $5-10 \%$ of patients with PMF. Mutations in exon 10 of the thrombopoietin receptor MPL gene result in amino acid changes of tryptophan 515 to leucine, lysine, or alanine (W515L/K/A), which is located within the cytoplasmic domain, proximal to the transmembrane domain $[2,10]$. These mutations result in conformation changes of the receptor that mimic the consequences of TPO binding, such that cytoplasmic JAK2 molecules are brought into close proximity, thus promoting their activation, transphosphorylation, and ligand-independent intracellular signaling.

In 2013, mutations in calreticulin (CALR), an endoplasmic reticulum (ER) chaperone responsible for the appropriate folding of protein before their trafficking either to the cell surface or for extracellular secretion, were identified in around one-third of patients with PMF [11,12]. CALR mutations occur as heterozygous insertions and/or deletions that are all located in the last exon of the gene (exon 9). Although $>50$ different $C A L R$ mutations have been identified, all result in a $+1 \mathrm{bp}$ frameshift to an alternative reading frame that alters the amino acid composition in the C-terminal part of the protein from acidic residues to basic residues and also leads to a loss of its ER retention signal KDEL. Mutant CALR complexes with MPL and results in its constitutive activation [13-15]. The extracellular domain of MPL, along with both the N-terminal and mutant C-terminal of CALR, appear necessary for this interaction, which may be facilitated by the newly acquired positive electrostatic charge within the $\mathrm{C}$ terminus [14,16]. CALR mutations were originally classified as type 1 (52-bp deletion) and type 2 (5-bp insertion) on the basis that these mutations are the most common, accounting for around $50 \%$ and $30 \%$ CALR mutations, respectively [11]. This classification was later refined to encompass type 1 and type 1-like (65\%), type 2 and type 2-like (32\%), and other (3\%) groups, with these categories defined according to the modification of the alpha-helix structure of the mutant protein, and on the absence or presence of a residual calcium-binding domain, as a consequence of the deletion of negatively charged amino acids stretches in the wild-type CALR C terminus [17]. In detail, type 1 and type 1-like mutations result in the deletion of 2 stretches of negatively charged amino acids; type 2 and type 2-like mutations do not result in the deletion of negatively charged residues, and other mutations result in the deletion of 1 stretch of negatively charged amino acids. The classification of CALR mutations is relevant for MPN phenotype and prognosis, as will be discussed in the next section.

Patients who do not carry JAK2 V617F mutation, exon 10 MPL mutations, and exon 9 CALR mutations are defined as "triple-negative". A few of these patients carry non-canonical mutations in JAK2 and MPL [18,19]. Therefore, the entire coding region of JAK2 and MPL may need to be covered for a complete diagnostic workup of these selected cases. Overall, $10 \%$ of patients with PMF have, as-yet, undiscovered drivers of their disease. Triple-negative MPN is particularly difficult to be diagnosed and differentiated from other myeloid disorders [20]. Recently, nonsense or frameshift mutations in the MLL3 gene that codes for ad epigenetic modifier (histone methyltransferase) have been reported in a fraction of triple-negative MPN patients [21]. The same kind of mutations have been identified in acute myeloid leukemia (AML) [22], thus suggesting it may act as a tumor suppressor in myeloid neoplasms.

Approximately one-third of patients with PMF harbor additional mutations in known drivers of myeloid malignancies. These mutations impact the process of DNA methylation (TET2, DNMT3A, IDH1/2), chromatin modifications (ASXL1, EZH2), RNA splicing (SF3B1, SRSF2, U2AF1), and DNA repair (TP53).

These observations have been acknowledged from a diagnostic standpoint, so that, in the absence of $J A K 2, C A L R$, or MPL mutations, the presence of one of the most frequent accompanying mutations (ASXL1, EZH2, TET2, IDH1/IDH2, SRSF2, SF3B1) is now included among the major criteria for both prefibrotic-myelofibrosis (pre-PMF) and overt-myelofibrosis according to the 2016 World Health Organization (WHO) classification [23], as reported in Table 1. However, some of these mutations (in particular in TET2, DNMT3A, ASXL1) have been found in otherwise healthy persons, 
especially when older than 65 years, advocating caution in interpreting the results of genotyping for diagnosis in the absence of overt clinical and hematological abnormalities [24]. Then, the identification of these mutations in triple-negative patients should be carefully interpreted, taking into account also the other diagnostic criteria (clinical phenotype and blood cell count, together with bone marrow abnormalities), since they may be signs of an underlying, antecedent clonal hematopoiesis or may be shared with other myeloid neoplasms, as myelodysplastic syndromes (especially those with fibrosis) and low blast count AML [20]. Finally, the mutation profile in triple-negative patients might help in distinguishing true clonal MF from autoimmune MF. Differentiating between a clonal disease and a secondary phenomenon is, indeed, relevant from a therapeutic standpoint, since the latter is sensitive to steroid treatment [25].

Table 1. The revised 2016 World Health Organization (WHO) diagnostic criteria for primary myelofibrosis.

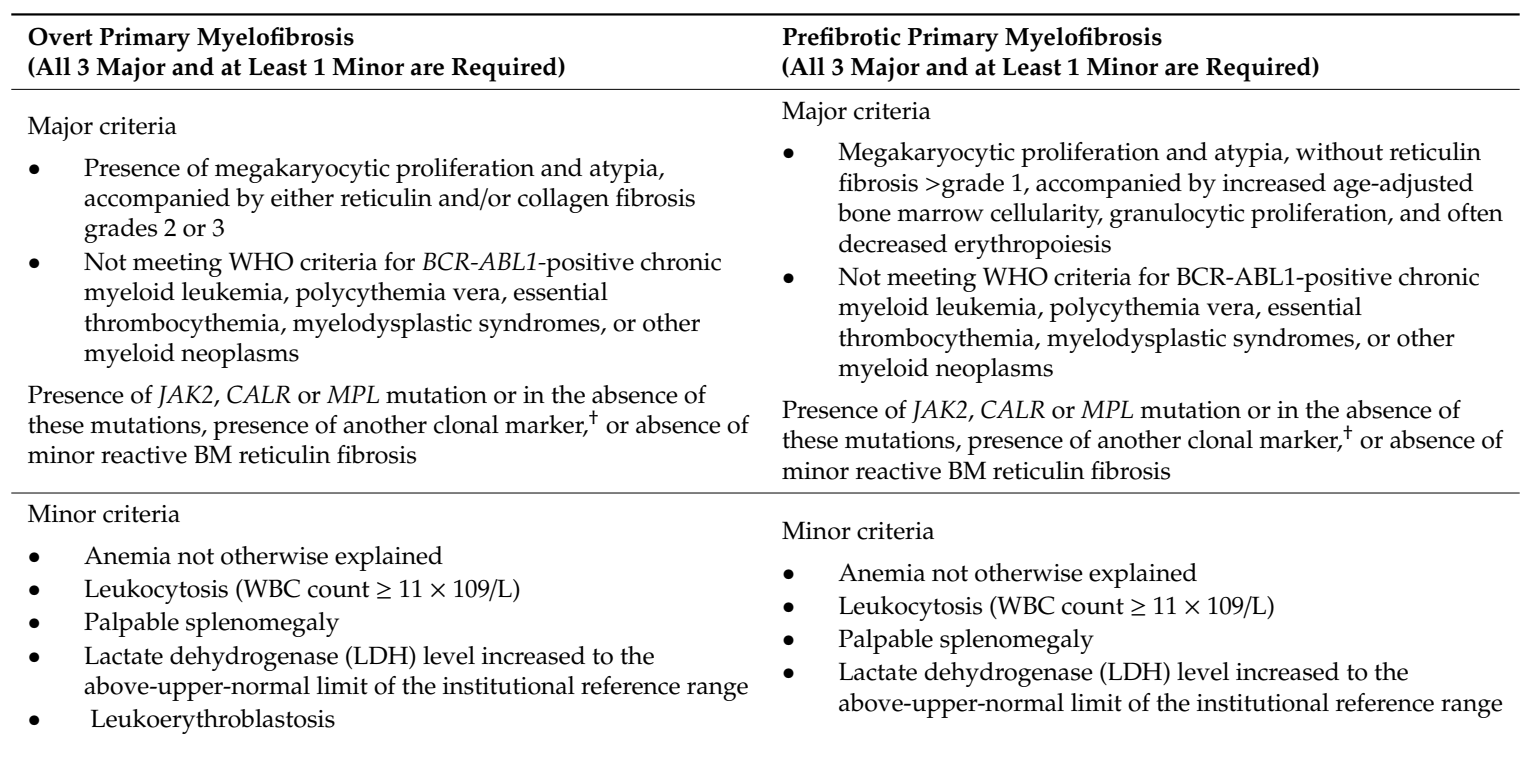

${ }^{\dagger}$ In the absence of any of the three major clonal mutations, the search for the most frequent accompanying mutations (e.g., ASXL1, EZH2, TET2, IDH1/2, SRSF2, SF3B1) are of help in determining the clonal nature of the disease.

\section{Mutation and Clinical Phenotype}

The type of mutation, mutation allele burden, order of acquisition, and combinations of genetic events may have an impact on the disease phenotype.

JAK2 V617F mutations in PMF are associated with older age, higher HB level, leukocytosis, and lower platelet count [26,27]. Conversely, CALR mutations in PMF have been shown to associate with younger age, higher platelet count, less frequent leukocytosis, anemia, and transfusion requirements, fewer spliceosome mutations, and lower dynamic international prognostic scoring system-plus (DIPSS-plus) scores compared with JAK2-mutated disease [11,28,29]. Some studies specifically aligned CALR type 1 variants with the aforementioned characteristics and phenotypically clustered type 2 variants with JAK2 mutants [29]. Direct comparison of type 1 and type 2 CALR mutations on the basis of hematological and clinical variables has yielded inconsistent findings. CALR type 2 mutations have been shown to correlate with higher risk DIPSS-plus scores, marked leukocytosis, and higher circulating blast percentage compared with type 1 variants [29], whereas other studies failed to observe any substantial phenotypic differences [17,30], Triple-negative PMF patients have been shown to be older, with lower $\mathrm{Hb}$ levels, platelet and leukocyte counts, and higher IPSS risk [28]. The risk of thrombosis is higher in JAK2 mutated PMF compared to CALR mutated PMF, despite the fact that calreticulin mutated patients display higher platelet counts, both in essential thrombocythemia and in 
PMF [28,31]. Thus, JAK2 V617F appears to be thrombophilic also in patients with PMF, as in patients with PV and ET.

Driver mutation allele burden may be another factor that influences the clinical course in PMF. Concerning survival, earlier studies identified a low JAK2 V617F allele burden as a risk factor for shortened survival in PMF [32,33], as compared to patients whose burden was higher than $50 \%$, suggesting a "burn out phase" of the disease, prone to bone mallow failure". Otherwise, newer investigations have found older age and high JAK2 allele burden to be associated with elevated plasma C-reactive protein levels and a pattern of progressive disease, supporting a potential relationship between allelic frequency, inflammation, and disease evolution [34]. Though debated, a high allele burden has also been associated with a greater likelihood of achieving a spleen response under JAK-inhibitor treatment [35]. Concerning the vascular risk, PMF patients with JAK2 V617F allele burden higher than $75 \%$ are high-risk patients as they are prone to develop thrombo-hemorrhagic complications during the disease course. A link between $C A L R$ mutation allelic burden and disease phenotype has been reported in the literature as it was demonstrated for JAK2 mutation. A high CALR allele burden is more frequent in PMF than in ET [36]. Patients with high CALR-mutant burden have acquired copy neutral loss of heterozygosity $(\mathrm{LOH})$ of chromosome $19 \mathrm{p}$, involving the transition from heterozygosity to homozygosity for the CALR mutation [11]. Anyway, 19pLOH appears to be a relatively uncommon event [37], in contrast with 9pLOH in JAK2-mutant MPN and 1pLOH in $M P L$-mutant MPN $[8,38,39]$. It has been suggested that the clonal expansion in CALR-mutant MPN is faster than that observed in JAK2-mutant MPN [40].

Somatic mutations in MPN do not seem to be acquired in a predetermined order as happens in other malignancies, but occur rather randomly [41]. The order of somatic mutation acquisition can be inferred from the genotypes of detectable subclones. For instance, if some tumor cells have JAK2 V617F, and other from the same patient bear JAK2 V617F with an additional somatic mutation, then this indicates that JAK2 V617F came first. The order of acquisition influences clinical presentation as it has been demonstrated for ET and PV: mutations in either DNMT3A or TET2 are associated with an ET phenotype when acquired prior to JAK2 V617F; by contrast, acquisition of JAK2 V617F prior to mutation of DNMT3A or TET2 is associated with PV [42,43]. Data regarding the impact of mutation order on clinical phenotype in myelofibrosis are still lacking, though we know that in patients with multiple mutations, JAK2 V617F was generally an earlier event in those with PMF [21].

Finally, also the germline genetic background might influence the molecular and cellular consequences of nascent PMF clones after their acquisition of phenotypic driver mutations [44].

Targeted sequencing of gene sets in myelofibrosis will be increasingly used in the near future because it will allow profiling of the mutational landscape of each patient and to better define the role of single or multiple, interacting mutations on clinical phenotype and prognosis [21].

\section{Mutation and Prognosis}

Over the past 10 years, prognostic scoring systems have been developed for PMF, including the International Prognostic Scoring System (IPSS) in 2009 [45], the Dynamic International Prognostic Scoring System (DIPSS) in 2010 [46] and the DIPSS-plus in 2011 [47]. They are essentially based on clinical and hematologic parameters, the only genetic parameter being chromosomal abnormalities in the DIPSS-plus.

IPSS utilizes five independent predictors of inferior survival evaluated at initial diagnosis: age $>65$ years, hemoglobin $<10 \mathrm{~g} / \mathrm{dL}$, WBC count $>25 \times 109 / \mathrm{L}$, circulating blasts $\geq 1 \%$, and presence of constitutional symptoms. Scores ranging from 0 to $\geq 3$ define four risk groups (low, intermediate 1 , intermediate 2, and high-risk) with a corresponding median survival of 11.3, 7.9, 4, and 2.3 years [45].

IPSS was subsequently modified into the DIPSS, which uses the same prognostic variables but assigns 2 points instead of 1 to hemoglobin $<10 \mathrm{~g} / \mathrm{dL}$ and can be applied at any time during the disease course [46]. 
DIPSS was further refined by incorporating three additional DIPSS-independent risk factors: unfavorable karyotype, PLT count lower than $100 \times 10^{9} / \mathrm{L}$, and transfusion requirement. The new prognostic model, DIPSS-plus, identifies four risk groups with median survival ranging from 15.4 to 1.3 years [47].

With the increasing knowledge of the molecular basis of PMF, it is becoming evident that both driver and non-driver mutations have relevance in terms of prognostic significance. PMF carrying CALR mutations [28], especially CALR type-1 mutations [29], have the best prognosis, whereas "triple-negative" PMF have the worst prognosis $[28,48]$. However, different mutations may interact with each other and modulate prognosis, as it has been shown for CALR and ASXL1: the best survival has been, indeed, reported for those patients harboring a CALR mutation with wild type ASXL1, while patients with the opposite genotype (CALR wild type and ASXL1 mutated) displayed a significantly worse prognosis. A third risk category could be identified, including those patients with both mutations or wild type for both genes [49].

This is somewhat similar to the AML scenario, where both NPM1 and FLT3 mutational status do influence prognosis [50].

Mutations in ASXL1, EZH2, SRSF2, or IDH1/2, called high molecular risk (HMR) mutations, have been shown to represent unfavorable prognostic factors, as these genetic lesions identify PMF patients who are at risk for premature death or leukemic transformation independently of the conventional prognostic scoring systems [27]. Moreover, the number of detrimental mutations represents an additional unfavorable prognostic factor, with two or more mutations being associated with shortened leukemia-free survival [51]. The frequency of HMR mutations and their prognostic consequences seems to be somewhat different between the two PMF subtypes: indeed, an HMR status has been less frequently reported in pre-PMF (27.0\%) than in overt PMF (44.4\%), while the negative prognostic effect of harboring more than one HMR mutations seems to be higher in pre-PMF, though statistically significant in both entities [52]. The presence of HMR mutations is also associated with a shorter time to treatment failure in patients treated with JAK inhibitors [53].

Together with the above-mentioned HMR mutations, genetic events occurring in the RAS/MAPK pathway genes have been recently associated with high-risk clinical features and worse prognosis, compared with wild type patients [54].

Then in 2018, a clinical/molecular prognostic model that includes both driver mutations and detrimental co-operating mutations was created. The Mutation-Enhanced International Prognostic Score System (MIPSS-70) includes the following risk factors: hemoglobin $<10 \mathrm{~g} / \mathrm{dL}$, abnormal leukocyte count (either $<4$ or $>25 \times 10^{9} / \mathrm{L}$ ), platelet count $<100 \times 10^{9} / \mathrm{L}$, circulating blasts $\geq 2 \%$, constitutional symptoms, bone marrow fibrosis grade, IPSS/DIPPS-plus category, driver mutations, absence of CALR type 1-like mutation, individual HMR mutations, HMR category, and the presence of $\geq 2 \mathrm{HMR}$ mutations. Each parameter has a weight of 1 point, except for leukocytosis, thrombocytopenia, and the presence of $\geq 2$ HMR mutations, which are each weighted 2 points. Patients are stratified into three categories: low-risk with a median survival of 27.7 years, intermediate-risk with a median survival of 7.1 years, and high-risk with a median survival of 2.3 years. In the MIPPS-70 plus that includes cytogenetic information, four risk categories are delineated with median survival ranging from 1.7 to 20 years [55]. The primary aim of this new score is to better select patient candidates for allogeneic bone marrow transplantation.

Later two new prognostic systems for PMF were introduced: the MIPSS70+ version 2.0 (mutationand karyotype-enhanced international prognostic scoring system) and the GIPSS (Genetically Inspired Prognostic Scoring System).

The MIPSS70+ version 2.0 incorporates the recently revised three-tiered cytogenetic risk levels [56], U2AF1Q157 as an additional HMR mutation, and new sex- and severity-adjusted hemoglobin thresholds (severe anemia for hemoglobin levels $<8 \mathrm{~g} / \mathrm{dL}$ in women and $<9 \mathrm{~g} / \mathrm{dL}$ in men, moderate anemia for hemoglobin levels of 8-9.9 g/dL in women and 9-10.9 g/dL in men). MIPPS70+ version 2.0 includes five genetic and four clinical variables: very high risk (VHR) karyotype (4 points), unfavorable karyotype 
( 3 points), presence of one ( 2 points) or $\geq 2$ HMR mutations ( 3 points), absence of type 1/like CALR mutation ( 2 points), constitutional symptoms ( 2 points), severe anemia ( 2 points), moderate anemia, ( 1 point) and circulating blasts $\geq 2 \%$ (1 point). MIPSS70+ version 2.0 features five risk categories: very high risk ( $\geq 9$ points); high risk (5-8 points); intermediate risk (3-4 points); low risk (1-2 points); and very low risk (zero points), with corresponding median survivals of 1.8 years, 4.1 years, 7.7 years, 16.4 years and "not reached" [57,58].

GIPSS, which is based exclusively on mutations and karyotype, represented the first attempt to model PMF survival on genetic features that fully replace traditional clinical variables, ads VHR karyotype ( 2 points), unfavorable karyotype (1 point), absence of type 1/like CALR mutation (1 point) and presence of ASXL1 (1 point) SRSF2 (1 point) and U2AF1Q157 (1 point) mutations. The GIPSS features four risk categories: high risk ( $\geq 3$ points), intermediate- 2 risk ( 2 points), intermediate- 1 (1 point), and low risk (zero points), with corresponding median survivals of 2 years, 4.2 years, 8.0 years, and 26.4 years [59]. The currently available prognostic scores are reported in Table 2 and represented in Figure 1.

Table 2. Prognostic models in primary myelofibrosis.

\begin{tabular}{|c|c|}
\hline Prognostic Model & Risk Groups and Clinical Relevance \\
\hline \multicolumn{2}{|c|}{ International Prognostic Scoring System (IPSS) [45] IPSS estimates survival at the time of diagnosis. } \\
\hline $\begin{array}{l}\text { Risk factors (weight): } \\
\text { - } \quad \text { Age }>65 \text { years }(1 \text { point }) \\
\text { - } \quad \text { Constitutional symptoms ( } 1 \text { point }) \\
\text { - } \quad \text { Hemoglobin }<10 \mathrm{~g} / \mathrm{dL} \text { ( } 1 \text { point }) \\
\left.\text { - } \quad \text { WBC count }>25 \times 10^{9} / \mathrm{L} \text { ( } 1 \text { point }\right) \\
\text { - }\end{array}$ & $\begin{array}{l}\text { Low risk: } 0 \text { (median survival } 11.3 \text { years) } \\
\text { Intermediate- } 1 \text { risk: } 1 \text { point ( } 7.9 \text { years) } \\
\text { Intermediate- } 2 \text { risk: } 2 \text { points ( } 4.0 \text { years) } \\
\text { High risk: } \geq 3 \text { points ( } 2.3 \text { years) }\end{array}$ \\
\hline \multicolumn{2}{|c|}{ Dynamic International Prognostic Scoring System (DIPSS) [46] DIPSS can be applied anytime during clinical course. } \\
\hline $\begin{array}{l}\text { Risk factors (weight): } \\
\text { - } \quad \text { Age }>65 \text { years }(1 \text { point }) \\
\text { - } \quad \text { Constitutional symptoms ( } 1 \text { point }) \\
\text { - } \quad \text { Hemoglobin }<10 \mathrm{~g} / \mathrm{dL}(2 \text { points }) \\
\text { - } \quad \text { WBC count }>25 \times 109 / \mathrm{L}(1 \text { point }) \\
\text { Circulating blasts } \geq 1 \% \text { ( } 1 \text { point })\end{array}$ & $\begin{array}{l}\text { Low risk: } 0 \text { (median survival: not reached) } \\
\text { Intermediate- } 1 \text { risk: } 1 \text { point ( } 14.2 \text { years) } \\
\text { Intermediate- } 2 \text { risk: } 2 \text { points }(4.0 \text { years) } \\
\text { High risk: } \geq 3 \text { points ( } 1.5 \text { years) }\end{array}$ \\
\hline \multicolumn{2}{|l|}{ DIPSS-plus [47] DIPSS-plus can be applied anytime during the clinical course. } \\
\hline $\begin{array}{l}\text { Risk factors (weight): } \\
\text { - } \quad \text { DIPSS score (DIPPS low }=0 \text {, DIPPS int- } 1=1 \text { point, DIPPS int- } 2=2 \text { points, } \\
\text { DIPSS high }=3 \text { points) } \\
\text { - } \quad \text { RBC transfusion need }(1 \text { point }) \\
\text { - } \quad \text { PLT count }<100 \times 109 / \mathrm{L}(1 \text { point }) \\
\text { - Unfavorable karyotype ( } 1 \text { point })\end{array}$ & $\begin{array}{l}\text { Low risk: } 0 \text { (median survival: } 15.4 \text { years) } \\
\text { Intermediate- } 1 \text { risk: } 1 \text { point ( } 6.5 \text { years) } \\
\text { Intermediate- } 2 \text { risk: } 2 \text { points ( } 2.9 \text { years) } \\
\text { High risk: } \geq 3 \text { points ( } 1.3 \text { years) }\end{array}$ \\
\hline \multicolumn{2}{|c|}{ MIPSS70 [55] MIPSS70 is used to better select patients $<70$ years as candidates for allogeneic stem cell transplantation. } \\
\hline $\begin{array}{ll}\text { Risk factors (weight): } \\
\text { - } & \text { One HMR mutation ( } 1 \text { point) } \\
\text { - } & \geq 2 \text { HMR mutation ( } 2 \text { points }) \\
\text { - } & \text { Type } 1 / \text { like CALR absent ( } 1 \text { point) } \\
\text { - } & \mathrm{Hb}<10 \mathrm{~g} / \mathrm{L} \text { ( } 1 \text { point) } \\
\text { - } & \mathrm{WBC}>25 \times 109 / \mathrm{L}(2 \text { points }) \\
\text { - } & \text { PLT count }<100 \times 109 / \mathrm{L} \text { ( } 2 \text { points }) \\
\text { - } & \text { Circulating blasts } \geq 2 \% \text { ( } 1 \text { point }) \\
\text { - } & \text { Constitutional symptoms ( } 1 \text { point }) \\
\text { - } & \text { Bone marrow fibrosis } \geq 2 \text { (1 point) }\end{array}$ & $\begin{array}{l}\text { Low risk: } 0-1 \text { points (median survival: } 27.7 \text { years) } \\
\text { Intermediate risk: } 2-4 \text { points ( } 7.1 \text { years) } \\
\text { High risk: } \geq 5 \text { points ( } 2.3 \text { years) }\end{array}$ \\
\hline
\end{tabular}


Table 2. Cont.
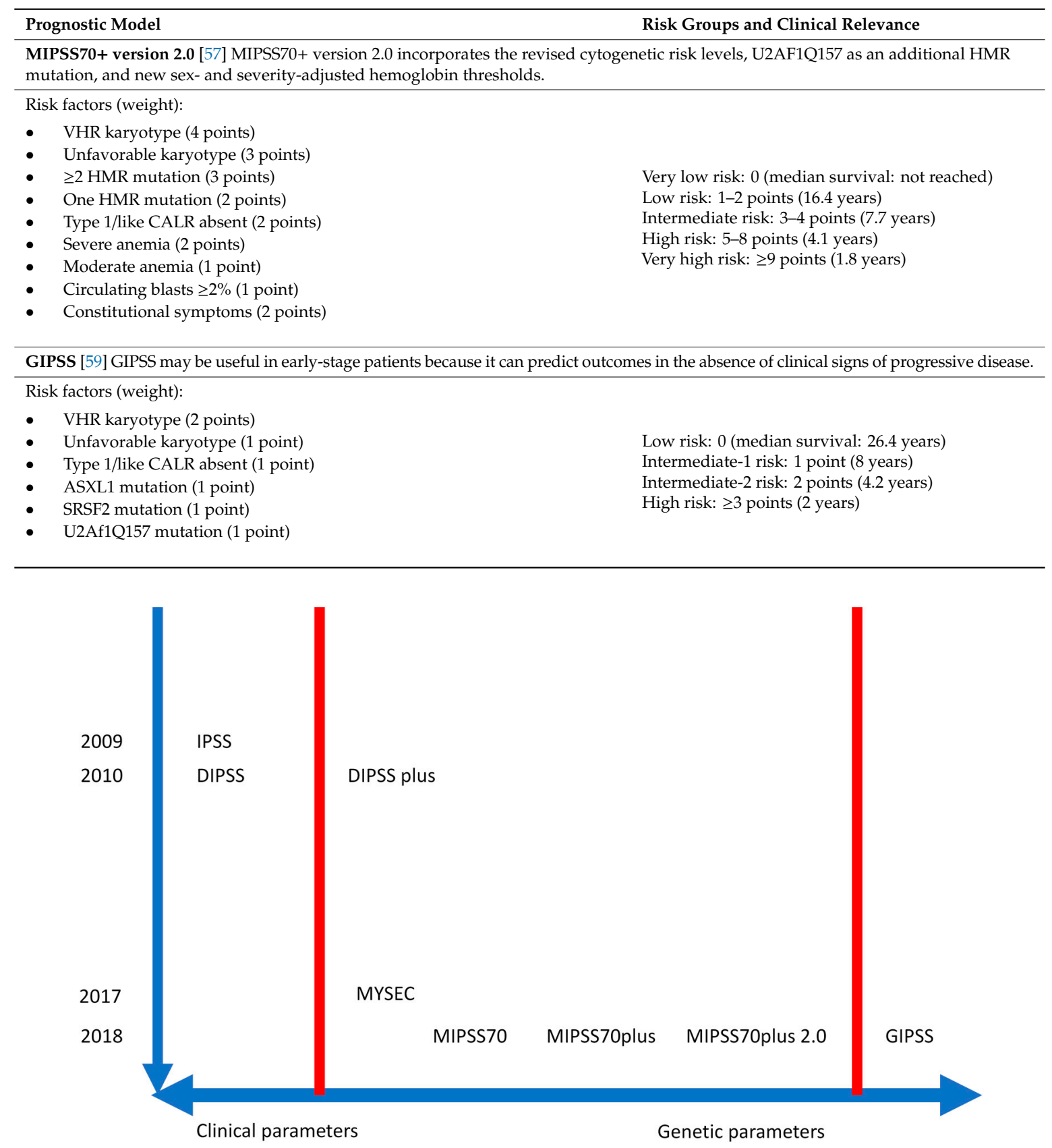

Figure 1. The different scores developed during the last two decades are based only on clinical parameters (IPSS and DIPSS), on clinical and genetic parameters (DIPSS plus, MYSEC, MIPSS70, MIPSS70plus, MIPSS70plus 2.0), or on genetic parameters only (GIPSS).

\section{Mutation and Treatment Response}

\subsection{Impact on Response to JAK Inhibitors or Interferon}

The clinical efficacy of ruxolitinib in myelofibrosis seems not to be affected by the underlying driver mutations $[60,61]$, but may be influenced by non-driver genetic events, especially when present in a high number. Patients with $\geq 3$ mutations from a customized, myeloid neoplasms-associated gene panel have a shorter time to treatment discontinuation and shorter overall survival than those with fewer mutations [62]. Moreover, drug efficacy, in terms of both symptoms and spleen response at 
6 months, has been recently reported to be lower in patients harboring mutations in the RAS/MAPK pathway, as NRAS, KRAS, or CBL [54].

Furthermore, drug failure has been associated with signs of clonal evolution in a not negligible percentage of cases, ranging from $17 \%$ in a cohort of real-life treated patients to $33 \%$ in a clinical trial setting, with a consistently negative impact on patients' survival $[63,64]$.

In addition, the response to other JAK-inhibitors, such as momelotinib or imetelestat, may be influenced by the presence of ASXL1/SRSF2 or ASXL1 mutations, respectively [65,66]. The clinical efficacy of interferon (IFN) in myelofibrosis seems not to be affected by the underlying driver mutations but may be influenced by HMR mutations $[67,68]$.

\subsection{Impact on Transplant Outcome}

Different mutations may have an impact on the outcome after hematopoietic bone marrow transplantation (HSCT). Early smaller reports suggested a benefit for JAK2 positive patients [69], whereas later studies demonstrated a positive impact for $C A L R$ positive patients and a negative impact on patients' prognosis of triple-negative status [70]. However, in those studies, only driver mutations were investigated. To determine the impact of molecular genetics on outcome after HSCT, the group of Kroger screened 169 patients affected with myelofibrosis for 16 frequently mutated genes [71]. CALR mutation was an independent factor for lower non-relapse mortality, improved progression-free survival (PFS), and overall survival. ASXL1 and IDH2 mutations were independent risk factors for lower PFS, whereas no impact was observed for triple-negative patients. Authors concluded that molecular genetics, especially CALR, IDH2, and ASXL1 mutations, may thus be useful to predict outcomes independently from known clinical risk factors after HSCT. Very recently, driver and subclonal mutations were incorporated in the myelofibrosis transplant score (MTSS), a scoring system that includes clinical-molecular and transplant-specific factors, with the aim of predicting posttransplant outcome. Multivariable analysis on survival identified age $\geq 57$ years, Karnofsky performance status $<90 \%$, platelet count $<150 \times 109 / \mathrm{L}$, and leukocyte count $>25 \times 109 / \mathrm{L}$ prior to transplantation, HLA-mismatched unrelated donor, ASXL1 mutation and non-CALR/MPL driver mutation genotype being independent predictors of outcome [72].

\subsection{Minimal Residual Disease (MRD)}

The presence of myelofibrosis-specific molecular markers offers the possibility to monitor the depth of remission after HSCT and to start a preemptive therapy at the first, minimal reappearance of disease [73-75]. The importance of the clearance of JAK2/CALR/MPL mutation was recently demonstrated in a cohort of 136 patients who received alloHSCT. Patients with detectable mutations at day +100 or at day +180 had a significantly higher risk of clinical relapse at 5 years than molecular-negative patients ( $62 \%$ vs. $10 \%, p<0.001$ ) [76]. Minimal residual disease (MRD) detection is clinically relevant as it may prompt a reduction of immunosuppressive agents or a donor-derived leukocyte infusion (DLI). The latter, in detail, is more effective when used for a molecular rather than for a clinical relapse [77]. The sensitivity of the method to detect MRD is pivotal. For JAK2 and MPL, a sensitivity of $10^{-5}$ has been described by PCR technique [73,74].

Notably, a JAK2 V617F qPCR assay was generally recommended because of its sensitivity and consistent performance across different qPCR platforms [78-80].

The use of CALR mutation as a marker of MRD is more problematic due to the variety of indels reported in the $C A L R$ gene and the scarce quantification accuracy of fragment length analysis and Sanger sequencing. Both a sensitive qPCR approach and a digital PCR assay that allows the accurate determination of CALR allelic burden for the most frequent alterations (type 1 and type 2) have been developed [81,82]. In addition, very sensitive digital PCR assays have been described for the detection of low JAK2 and CALR mutant burdens [83].

Subclonal mutations, if present, could be extremely useful to monitor MRD, both in triple-negative patients or as an additional tool for those who have a traditional driver event. In this regard, 
next-generation sequencing (NGS) approaches for MRD monitoring might be hopefully developed in the future.

\section{Conclusions}

The rapidly expanding field of molecular genetics for myelofibrosis has opened new horizons in the diagnosis, prognosis, treatment decision-making, and monitoring of this disorder. Recommendations for molecular testing in MPN has been recently provided [84] and include both driver and non-driver genetic events. The latter may aid in the diagnostic process of patients who tested negative for the three driver mutations, in which an extended mutation panel including at least ASXL1, EZH2, IDH1/2, and SRSF2 is recommended. The same extended panel is also appropriate for prognostic prediction, in particular for patients classified as intermediate risk, for which treatment allocation, counseling and/or frequency of monitoring may be refined according to the individual genetic background. High-sensitivity quantitative monitoring of $J A K 2 \mathrm{~V} 617 \mathrm{~F}$ and $C A L R$ mutations, or quantitative evaluation of another clonal marker in triple-negative patients, are recommended in all patients after HSCT for MRD assessment.

While comprehensive gene sequencing of hematological cancer patients is becoming an increasingly accessible event for routine clinical use, many uncertainties still remain. As an example, how many times should PMF patients be tested? In fact, MPNs are dynamic diseases, so that high-risk genomic features may be gained over time, requiring treatment intervention (or HSCT consideration).

Genome profiling will likely become the basis for a personally-tailored prognosis prediction, but we acknowledge that clinical translation of recent scientific advances is still a work in progress.

Author Contributions: E.R. and E.S. conceived and wrote the review, C.T., D.V., I.C.C., and D.P. contributed to finalizing the manuscript. All authors have read and agreed to the published version of the manuscript.

Funding: This work was supported by a grant from the Italian Ministry of Health for young researchers (GR-2016-02361272) to E.R.

Conflicts of Interest: The authors declare no conflict of interest.

\section{References}

1. Mora, B.; Siracusa, C.; Rumi, E.; Maffioli, M.; Casetti, I.C.; Barraco, D.; Merli, M.; Rossi, M.; Ubezio, M.; Accetta, R.; et al. Platelet count predicts driver mutations' co-occurrence in low JAK2 mutated essential thrombocythemia and myelofibrosis. Leukemia 2020, 1-4. [CrossRef]

2. Pikman, Y.; Lee, B.H.; Mercher, T.; McDowell, E.; Ebert, B.L.; Gozo, M.; Cuker, A.; Wernig, G.; Moore, S.; Galinsky, I.; et al. MPLW515L Is a Novel Somatic Activating Mutation in Myelofibrosis with Myeloid Metaplasia. PLoS Med. 2006, 3, e270. [CrossRef]

3. Mullally, A.; Lane, S.W.; Ball, B.; Megerdichian, C.; Okabe, R.; Al-Shahrour, F.; Paktinat, M.; Haydu, J.E.; Housman, E.; Lord, A.M.; et al. Physiological Jak2V617F Expression Causes a Lethal Myeloproliferative Neoplasm with Differential Effects on Hematopoietic Stem and Progenitor Cells. Cancer Cell 2010, 17, 584-596. [CrossRef]

4. Andrikovics, H.; Krahling, T.; Balassa, K.; Halm, G.; Bors, A.; Koszarska, M.; Batai, A.; Dolgos, J.; Csomor, J.; Egyed, M.; et al. Distinct clinical characteristics of myeloproliferative neoplasms with calreticulin mutations. Haematologica 2014, 99, 1184-1190. [CrossRef]

5. Li, J.; Prins, D.; Park, H.J.; Grinfeld, J.; Gonzalez-Arias, C.; Loughran, S.; Dovey, O.M.; Klampfl, T.; Bennett, C.; Hamilton, T.L.; et al. Mutant calreticulin knockin mice develop thrombocytosis and myelofibrosis without a stem cell self-renewal advantage. Blood 2018, 131, 649-661. [CrossRef]

6. Baxter, E.J.; Scott, L.M.; Campbell, P.J.; East, C.; Fourouclas, N.; Swanton, S.; Vassiliou, G.S.; Bench, A.J.; Boyd, E.M.; Curtin, N.; et al. Acquired mutation of the tyrosine kinase JAK2 in human myeloproliferative disorders. Lancet 2005, 365, 1054-1061. [CrossRef]

7. James, C.; Ugo, V.; Le Couédic, J.P.; Staerk, J.; Delhommeau, F.; Lacout, C.; Garçon, L.; Raslova, H.; Berger, R.; Bennaceur-Griscelli, A.; et al. A unique clonal JAK2 mutation leading to constitutive signalling causes polycythaemia vera. Nature 2005, 43, 1144-1148. [CrossRef] [PubMed] 
8. Kralovics, R.; Passamonti, F.; Buser, A.S.; Teo, S.-S.; Tiedt, R.; Passweg, J.R.; Tichelli, A.; Cazzola, M.; Skoda, R.C. A Gain-of-Function Mutation ofJAK2in Myeloproliferative Disorders. N. Engl. J. Med. 2005, 352, 1779-1790. [CrossRef] [PubMed]

9. Levine, R.L.; Wadleigh, M.; Cools, J.; Ebert, B.L.; Wernig, G.; Huntly, B.J.; Boggon, T.J.; Wlodarska, I.; Clark, J.J.; Moore, S.; et al. Activating mutation in the tyrosine kinase JAK2 in polycythemia vera, essential thrombocythemia, and myeloid metaplasia with myelofibrosis. Cancer Cell 2005, 7, 387-397. [CrossRef]

10. Pardanani, A.D.; Levine, R.L.; Lasho, T.; Pikman, Y.; Mesa, R.; Wadleigh, M.; Steensma, D.P.; Elliott, M.; Wolanskyj, A.P.; Hogan, W.J.; et al. MPL515 mutations in myeloproliferative and other myeloid disorders: A study of 1182 patients. Blood 2006, 108, 3472-3476. [CrossRef] [PubMed]

11. Klampfl, T.; Gisslinger, H.; Harutyunyan, A.S.; Nivarthi, H.; Rumi, E.; Milosevic, J.D.; Them, N.C.C.; Berg, T.; Gisslinger, B.; Pietra, D.; et al. Somatic Mutations of Calreticulin in Myeloproliferative Neoplasms. N. Engl. J. Med. 2013, 369, 2379-2390. [CrossRef] [PubMed]

12. Nangalia, J.; Massie, C.; Baxter, E.; Nice, F.; Gundem, G.; Wedge, D.; Avezov, E.; Li, J.; Kollmann, K.; Kent, D.; et al. SomaticCALRMutations in Myeloproliferative Neoplasms with NonmutatedJAK2. N. Engl. J. Med. 2013, 369, 2391-2405. [CrossRef] [PubMed]

13. Araki, M.; Yang, Y.; Masubuchi, N.; Hironaka, Y.; Takei, H.; Morishita, S.; Mizukami, Y.; Kan, S.; Shirane, S.; Edahiro, Y.; et al. Activation of the thrombopoietin receptor by mutant calreticulin in CALR-mutant myeloproliferative neoplasms. Blood 2016, 127, 1307-1316. [CrossRef] [PubMed]

14. Chachoua, I.; Pecquet, C.; El-Khoury, M.; Nivarthi, H.; Albu, R.-I.; Marty, C.; Gryshkova, V.; Defour, J.-P.; Vertenoeil, G.; Ngo, A.; et al. Thrombopoietin receptor activation by myeloproliferative neoplasm associated calreticulin mutants. Blood 2016, 127, 1325-1335. [CrossRef]

15. Marty, C.; Pecquet, C.; Nivarthi, H.; El-Khoury, M.; Chachoua, I.; Tulliez, M.; Villeval, J.-L.; Raslova, H.; Kralovics, R.; Constantinescu, S.N.; et al. Calreticulin mutants in mice induce an MPL-dependent thrombocytosis with frequent progression to myelofibrosis. Blood 2016, 127, 1317-1324. [CrossRef]

16. Elf, S.; Abdelfattah, N.S.; Chen, E.; Perales-Patón, J.; Rosen, E.A.; Ko, A.; Peisker, F.; Florescu, N.; Giannini, S.; Wolach, O; et al. Mutant Calreticulin Requires Both Its Mutant C-terminus and the Thrombopoietin Receptor for Oncogenic Transformation. Cancer Discov. 2016, 6, 368-381. [CrossRef]

17. Pietra, D.; Rumi, E.; Ferretti, V.V.; Di Buduo, C.A.; Milanes, C.; Cavalloni, C.; Sant'Antonio, E.; Abbonante, V.; Moccia, F.; Casetti, I.C.; et al. Differential clinical effects of different mutation subtypes in CALR-mutant myeloproliferative neoplasms. Leukemia 2016, 30, 431-438. [CrossRef]

18. Cabagnols, X.; Favale, F.; Pasquier, F.; Messaoudi, K.; Defour, J.P.; Ianotto, J.-C.; Marzac, C.; Le Couédic, J.P.; Droin, N.; Chachoua, I.; et al. Presence of atypical thrombopoietin receptor (MPL) mutations in triple-negative essential thrombocythemia patients. Blood 2016, 127, 333-342. [CrossRef]

19. Feenstra, J.D.M.; Nivarthi, H.; Gisslinger, H.; Leroy, E.; Rumi, E.; Chachoua, I.; Bagienski, K.; Kubesova, B.; Pietra, D.; Gisslinger, B.; et al. Whole-exome sequencing identifies novel MPL and JAK2 mutations in triple-negative myeloproliferative neoplasms. Blood 2016, 127, 325-332. [CrossRef]

20. Papaemmanuil, E.; Döhner, H.; Campbell, P.J. Genomic Classification in Acute Myeloid Leukemia. N. Engl. J. Med. 2016, 374, 2209-2221. [CrossRef]

21. Grinfeld, J.; Nangalia, J.; Baxter, E.J.; Wedge, D.C.; Angelopoulos, N.; Cantrill, R.; Godfrey, A.L.; Papaemmanuil, E.; Gundem, G.; MacLean, C.; et al. Classification and Personalized Prognosis in Myeloproliferative Neoplasms. N. Engl. J. Med. 2018, 379, 1416-1430. [CrossRef] [PubMed]

22. Chen, C.; Liu, Y.; Rappaport, A.R.; Kitzing, T.; Schultz, N.; Zhao, Z.; Shroff, A.S.; Dickins, R.A.; Vakoc, C.R.; Bradner, J.E.; et al. MLL3 Is a Haploinsufficient 7q Tumor Suppressor in Acute Myeloid Leukemia. Cancer Cell 2014, 25, 652-665. [CrossRef] [PubMed]

23. Arber, D.A.; Orazi, A.; Hasserjian, R.; Thiele, J.; Borowitz, M.J.; Le Beau, M.M.; Bloomfield, C.D.; Cazzola, M.; Vardiman, J.W. The 2016 revision to the World Health Organization classification of myeloid neoplasms and acute leukemia. Blood 2016, 127, 2391-2405. [CrossRef] [PubMed]

24. Genovese, G.; Kähler, A.K.; Handsaker, R.E.; Lindberg, J.; Rose, S.A.; Bakhoum, S.F.; Chambert, K.; Mick, E.; Neale, B.M.; Fromer, M.; et al. Clonal Hematopoiesis and Blood-Cancer Risk Inferred from Blood DNA Sequence. N. Engl. J. Med. 2014, 371, 2477-2487. [CrossRef] [PubMed]

25. Mertz, P.; Chalayer, E.; Amoura, Z.; Cathebras, P.; Chiche, L.; Coestedoat, N.; Deroux, A.; Diot, E.; Durupt, S.; Forestier, E.; et al. Clinical spectrum and therapeutic management of auto-immune myelofibrosis: A nation-wide study of 30 cases. Haematologica 2020. [CrossRef] 
26. Vannucchi, A.M.; Antonioli, E.; Guglielmelli, P.; Pardanani, A.; Tefferi, A. Clinical correlates of JAK2V617F presence or allele burden in myeloproliferative neoplasms: A critical reappraisal. Leukemia 2008, 22, 1299-1307. [CrossRef]

27. Vannucchi, A.M.; Lasho, T.L.; Guglielmelli, P.; Am, V.; Pardanani, A.; Pereira, A.; Finke, C.M.; Score, J.; Gangat, N.; Mannarelli, C.; et al. Mutations and prognosis in primary myelofibrosis. Leukemia 2013, 27, 1861-1869. [CrossRef]

28. Rumi, E.; Pietra, D.; Pascutto, C.; Guglielmelli, P.; Martínez-Trillos, A.; Casetti, I.; Colomer, D.; Pieri, L.; Pratcorona, M.; Rotunno, G.; et al. Clinical effect of driver mutations of JAK2, CALR, or MPL in primary myelofibrosis. Blood 2014, 124, 1062-1069. [CrossRef]

29. Tefferi, A.; Lasho, T.L.; Finke, C.; Belachew, A.A.; Wassie, E.A.; Ketterling, R.P.; Hanson, C.A.; Pardani, A. Type 1 vs. type 2 calreticulin mutations in primary myelofibrosis: Differences in phenotype and prognostic impact. Leukemia 2014, 28, 1568-1570. [CrossRef]

30. Tefferi, A.; Lasho, T.L.; Tischer, A.; Wassie, E.A.; Finke, C.M.; Belachew, A.A.; Ketterling, R.P.; Hanson, C.A.; Pardanani, A.D. The prognostic advantage of calreticulin mutations in myelofibrosis might be confined to type 1 or type 1-like CALR variants. Blood 2014, 124, 2465-2466. [CrossRef]

31. Finazzi, M.C.; Carobbio, A.; Cervantes, F.; Isola, I.M.; Vannucchi, A.M.; Guglielmelli, P.; Rambaldi, A.; Finazzi, G.; Barosi, G.; Barbui, T. CALR mutation, MPL mutation and triple negativity identify patients with the lowest vascular risk in primary myelofibrosis. Leukemia 2014, 29, 1209-1210. [CrossRef] [PubMed]

32. Tefferi, A.; Lasho, T.L.; Huang, J.; Finke, C.M.; Mesa, R.; Li, C.Y.; Wu, W.; Hanson, C.; Pardanani, A. Low JAK2V617F allele burden in primary myelofibrosis, compared to either a higher allele burden or unmutated status, is associated with inferior overall and leukemia-free survival. Leukemia 2008, 22, 756-761. [CrossRef] [PubMed]

33. Guglielmelli, P.; Barosi, G.; Specchia, G.; Rambaldi, A.; Lo-Coco, F.; Antonioli, E.; Pieri, L.; Pancrazzi, A.; Ponziani, V.; Delaini, F.; et al. Identification of patients with poorer survival in primary myelofibrosis based on the burden of JAK2V617F mutated allele. Blood 2009, 114, 1477-1483. [CrossRef] [PubMed]

34. Barosi, G.; Massa, M.; Campanelli, R.; Fois, G.; Catarsi, P.; Viarengo, G.; Villani, L.; Poletto, V.; Bosoni, T.; Magrini, U.; et al. Primary myelofibrosis: Older age and high JAK2 V617F allele burden are associated with elevated plasma high-sensitivity C-reactive protein levels and a phenotype of progressive disease. Leuk. Res. 2017, 60, 18-23. [CrossRef]

35. Barosi, G.; Klersy, C.; Villani, L.; Bonetti, E.; Catarsi, P.; Poletto, V.; Campanelli, R.; Impera, S.; Latagliata, R.; Viarengo, G.; et al. JAK2(V617F) allele burden $\geq 50 \%$ is associated with response to ruxolitinib in persons with MPN-associated myelofibrosis and splenomegaly requiring therapy. Leukemia 2016, 30, 1772-1775. [CrossRef]

36. Cabagnols, X.; Defour, J.P.; Ugo, V.; Ianotto, J.C.; Mossuz, P.; Mondet, J.; Girodon, F.; Alexandre, J.H.; Mansier, O.; Viallard, J.F.; et al. Differential association of calreticulin type 1 and type 2 mutations with myelofibrosis and essential thrombocytemia: Relevance for disease evolution. Leukemia 2015, 29, $249-252$. [CrossRef]

37. Rumi, E.; Pietra, D.; Ferretti, V.; Klampfl, T.; Harutyunyan, A.S.; Milosevic, J.D.; Them, N.C.C.; Berg, T.; Elena, C.; Casetti, I.C.; et al. JAK2 or CALR mutation status defines subtypes of essential thrombocythemia with substantially different clinical course and outcomes. Blood 2014, 123, 1544-1551. [CrossRef]

38. Godfrey, A.L.; Chen, E.; Pagano, F.; Ortmann, C.A.; Silber, Y.; Bellosillo, B.; Guglielmelli, P.; Harrison, C.N.; Reilly, J.T.; Stegelmann, F.; et al. JAK2V617F homozygosity arises commonly and recurrently in PV and ET, but PV is characterized by expansion of a dominant homozygous subclone. Blood 2012, 120, $2704-2707$. [CrossRef]

39. Rumi, E.; Pietra, D.; Guglielmelli, P.; Bordoni, R.; Casetti, I.; Milanesi, C.; Sant'Antonio, E.; Ferretti, V.V.; Pancrazzi, A.; Rotunno, G.; et al. Acquired copy-neutral loss of heterozygosity of chromosome $1 \mathrm{p}$ as a molecular event associated with marrow fibrosis in MPL-mutated myeloproliferative neoplasms. Blood 2013, 121, 4388-4395. [CrossRef]

40. Cavalloni, C.; Rumi, E.; Ferretti, V.V.; Pietra, D.; Roncoroni, E.; Bellini, M.; Ciboddo, M.; Casetti, I.C.; Landini, B.; Fugazza, E.; et al. Sequential evaluation of CALR mutant burden in patients with myeloproliferative neoplasms. Oncotarget 2017, 8, 33416-33421. [CrossRef]

41. Kralovics, R. Genetic complexity of myeloproliferative neoplasms. Leukemia 2008, 22, 1841-1848. [CrossRef] [PubMed] 
42. Nangalia, J.; Nice, F.L.; Wedge, D.C.; Godfrey, A.L.; Grinfeld, J.; Thakker, C.; Massie, C.E.; Baxter, J.; Sewell, D.; Silber, Y.; et al. DNMT3A mutations occur early or late in patients with myeloproliferative neoplasms and mutation order influences phenotype. Haematologica 2015, 100, e438-e442. [CrossRef] [PubMed]

43. Ortmann, C.A.; Kent, D.G.; Nangalia, J.; Silber, Y.; Wedge, D.C.; Grinfeld, J.; Baxter, E.J.; Massie, C.E.; Papaemmanuil, E.; Menon, S.; et al. Effect of mutation order on myeloproliferative neoplasms. N. Engl. J. Med. 2015, 372, 601-612. [CrossRef] [PubMed]

44. Hinds, D.A.; Barnholt, K.E.; Mesa, R.A.; Kiefer, A.K.; Do, C.B.; Eriksson, N.; Mountain, J.L.; Francke, U.; Tung, J.Y.; Nguyen, H.M.; et al. Germ line variants predispose to both JAK2 V617F clonal hematopoiesis and myeloproliferative neoplasms. Blood 2016, 128, 1121-1128. [CrossRef] [PubMed]

45. Hernández-Boluda, J.C.; Dupriez, B.; Pereira, A.; Passamonti, F.; Reilly, J.T.; Morra, E.; Vannucchi, A.M.; Mesa, R.A.; Demory, J.-L.; Barosi, G.; et al. New prognostic scoring system for primary myelofibrosis based on a study of the International Working Group for Myelofibrosis Research and Treatment. Blood 2009, 113, 2895-2901.

46. Passamonti, F.; Cervantes, F.; Vannucchi, A.M.; Morra, E.; Rumi, E.; Pereira, A.; Guglielmelli, P.; Pungolino, E.; Caramella, M.; Maffioli, M.; et al. A dynamic prognostic model to predict survival in primary myelofibrosis: A study by the IWG-MRT (International Working Group for Myeloproliferative Neoplasms Research and Treatment). Blood 2010, 115, 1703-1708. [CrossRef] [PubMed]

47. Gangat, N.; Caramazza, D.; Vaidya, R.; George, G.; Begna, K.; Schwager, S.; Van Dyke, D.; Hanson, C.; Wu, W.; Pardanani, A.; et al. DIPSS Plus: A Refined Dynamic International Prognostic Scoring System for Primary Myelofibrosis That Incorporates Prognostic Information From Karyotype, Platelet Count, and Transfusion Status. J. Clin. Oncol. 2011, 29, 392-397. [CrossRef]

48. Tefferi, A.; Lasho, T.L.; Finke, C.M.; Knudson, R.; Ketterling, R.P.; Hanson, C.H.; Maffioli, M.; Caramazza, D.; Passamonti, F.; Pardanani, A. CALR vs. JAK2 vs. MPL-mutated or triple-negative myelofibrosis: Clinical, cytogenetic and molecular comparisons. Leukemia 2014, 28, 1472-1477. [CrossRef]

49. Tefferi, A.; Guglielmelli, P.; Lasho, T.L.; Rotunno, G.; Finke, C.; Mannarelli, C.; Belachew, A.; Pancrazzi, A.; Wassie, E.; Ketterling, R.P.; et al. CALR and ASXL1 mutations-based molecular prognostication in primary myelofibrosis: An international study of 570 patients. Leukemia 2014, 28, 1494-1500. [CrossRef]

50. Bullinger, L.; Döhner, K.; Döhner, H. Genomics of Acute Myeloid Leukemia Diagnosis and Pathways. J. Clin. Oncol. 2017, 35, 934-946. [CrossRef]

51. Guglielmelli, P.; Lasho, T.L.; Biamonte, F.; Score, J.; Mannarelli, C.; Rotunno, G.; Pancrazzi, A.; Pardanani, A.; Zoi, K.; Reiter, A.; et al. Effect of the Number of Prognostically Relevant Mutated Genes on Survival and Leukemia Progression in Primary Myelofibrosis. Blood 2013, 122, 104. [CrossRef]

52. Guglielmelli, P.; Pacilli, A.; Rotunno, G.; Rumi, E.; Rosti, V.; Delaini, F.; Maffioli, M.; Fanelli, T.; Pancrazzi, A.; Pietra, D.; et al. Presentation and outcome of patients with 2016 WHO diagnosis of prefibrotic and overt primary myelofibrosis. Blood 2017, 129, 3227-3236. [CrossRef] [PubMed]

53. Spiegel, J.Y.; McNamara, C.; Kennedy, J.A.; Panzarella, T.; Arruda, A.; Stockley, T.; Sukhai, M.; Thomas, M.; Bartoszko, J.; Ho, M.J.; et al. Impact of genomic alterations on outcomes in myelofibrosis patients undergoing JAK1/2 inhibitor therapy. Blood Adv. 2017, 1, 1729-1738. [CrossRef] [PubMed]

54. Coltro, G.; Rotunno, G.; Mannelli, L.; Mannarelli, C.; Fiaccabrino, S.; Romagnoli, S.; Bartalucci, N.; Ravenda, E.; Gelli, E.; Sant'Antonio, E.; et al. RAS/CBL mutations predict resistance to JAK inhibitors in myelofibrosis and are associated with poor prognostic features. Blood Adv. 2020, 4, 3677-3687. [CrossRef]

55. Guglielmelli, P.; Lasho, T.; Rotunno, G.; Mudireddy, M.; Mannarelli, C.; Nicolosi, M.; Pacilli, A.; Pardanani, A.D.; Rumi, E.; Rosti, V.; et al. MIPSS70: Mutation-Enhanced International Prognostic Score System for Transplantation-Age Patients With Primary Myelofibrosis. J. Clin. Oncol. 2018, 36, 310-318. [CrossRef]

56. Tefferi, A.; Nicolosi, M.; Mudireddy, M.; Lasho, T.L.; Gangat, N.; Begna, K.H.; Hanson, C.A.; Ketterling, R.P.; Pardanani, A. Revised cytogenetic risk stratification in primary myelofibrosis: Analysis based on 1002 informative patients. Leukemia 2018, 32, 1189-1199. [CrossRef]

57. Tefferi, A.; Guglielmelli, P.; Lasho, T.; Gangat, N.; Ketterling, R.P.; Pardanani, A.D.; Vannucchi, A.M. MIPSS70+ Version 2.0: Mutation and Karyotype-Enhanced International Prognostic Scoring System for Primary Myelofibrosis. J. Clin. Oncol. 2018, 36, 1769-1770. [CrossRef] 
58. Tefferi, A.; Finke, C.M.; Lasho, T.L.; Hanson, C.A.; Ketterling, R.P.; Gangat, N.; Pardanani, A. U2AF1 mutation types in primary myelofibrosis: Phenotypic and prognostic distinctions. Leukemia 2018, 32, 2274-2278. [CrossRef]

59. Tefferi, A.; Lasho, T.L.; Mudireddy, M.; Finke, C.M.; Hanson, C.A.; Ketterling, R.P.; Gangat, N.; Pardanani, A. The germline JAK2 GGCC (46/1) haplotype and survival among 414 molecularly-annotated patients with primary myelofibrosis. Am. J. Hematol. 2019, 94, 299-305. [CrossRef]

60. Guglielmelli, P.; Biamonte, F.; Rotunno, G.; Artusi, V.; Artuso, L.; Bernardis, I.; Tenedini, E.; Pieri, L.; Paoli, C.; Mannarelli, C.; et al. Impact of mutational status on outcomes in myelofibrosis patients treated with ruxolitinib in the COMFORT-II study. Blood 2014, 123, 2157-2160. [CrossRef]

61. Guglielmelli, P.; Rotunno, G.; Bogani, C.; Mannarelli, C.; Giunti, L.; Provenzano, A.; Giglio, S.; Squires, M.; Stalbovskaya, V.; Gopalakrishna, P.; et al. Ruxolitinib is an effective treatment forCALR-positive patients with myelofibrosis. Br. J. Haematol. 2016, 173, 938-940. [CrossRef] [PubMed]

62. Patel, K.P.; Newberry, K.J.; Luthra, R.; Jabbour, E.; Pierce, S.; Cortes, J.; Singh, R.; Mehrotra, M.; Routbort, M.J.; Luthra, M.; et al. Correlation of mutation profile and response in patients with myelofibrosis treated with ruxolitinib. Blood 2015, 126, 790-797. [CrossRef]

63. Newberry, K.J.; Patel, K.; Masarova, L.; Luthra, R.; Manshouri, T.; Jabbour, E.; Bose, P.; Daver, N.; Cortes, J.; Kantarjian, H.; et al. Clonal evolution and outcomes in myelofibrosis after ruxolitinib discontinuation. Blood 2017, 130, 1125-1131. [CrossRef] [PubMed]

64. Pacilli, A.; Rotunno, G.; Mannarelli, C.; Fanelli, T.; Pancrazzi, A.; Contini, E.; Mannelli, F.; Gesullo, F.; Bartalucci, N.; Fattori, G.C.; et al. Mutation landscape in patients with myelofibrosis receiving ruxolitinib or hydroxyurea. Blood Cancer J. 2018, 8, 122. [CrossRef] [PubMed]

65. Tefferi, A.; Lasho, T.; Begna, K.H.; Patnaik, M.M.; Zblewski, D.L.; Finke, C.M.; Laborde, R.R.; Wassie, E.; Schimek, L.; Hanson, C.A.; et al. A Pilot Study of the Telomerase Inhibitor Imetelstat for Myelofibrosis. N. Engl. J. Med. 2015, 373, 908-919. [CrossRef]

66. Tefferi, A.; Barraco, D.; Lasho, T.L.; Shah, S.; Begna, K.H.; Al-Kali, A.; Hogan, W.J.; Litzow, M.R.; Hanson, C.A.; Ketterling, R.P.; et al. Momelotinib therapy for myelofibrosis: A 7-year follow-up. Blood Cancer J. 2018, 8, 29. [CrossRef]

67. Silver, R.T.; Barel, A.C.; Lascu, E.; Ritchie, E.; Roboz, G.J.; Christos, P.J.; Orazi, A.; Hassane, D.C.; Tam, W.; Cross, N.C.P. The effect of initial molecular profile on response to recombinant interferon- $\alpha(\mathrm{rIFN} \alpha)$ treatment in early myelofibrosis. Cancer 2017, 123, 2680-2687. [CrossRef]

68. Ianotto, J.-C.; Chauveau, A.; Boyer-Perrard, F.; Gyan, E.; Laribi, K.; Cony-Makhoul, P.; Demory, J.-L.; De Renzis, B.; Dosquet, C.; Rey, J.; et al. Benefits and pitfalls of pegylated interferon- $\alpha 2 a$ therapy in patients with myeloproliferative neoplasm-associated myelofibrosis: A French Intergroup of Myeloproliferative neoplasms (FIM) study. Haematologica 2017, 103, 438-446. [CrossRef] [PubMed]

69. Alchalby, H.; Badbaran, A.; Zabelina, T.; Kobbe, G.; Hahn, J.; Wolff, D.; Bornhäuser, M.; Thiede, C.; Baurmann, H.; Bethge, W.; et al. Impact of JAK2V617F mutation status, allele burden, and clearance after allogeneic stem cell transplantation for myelofibrosis. Blood 2010, 116, 3572-3581. [CrossRef]

70. Panagiota, V.; Thol, F.; Márkus, B.; Fehse, B.; Alchalby, H.; Badbaran, A.; Lehmann, U.; Koenecke, C.; Shahswar, R.; Chaturvedi, A.; et al. Prognostic effect of calreticulin mutations in patients with myelofibrosis after allogeneic hematopoietic stem cell transplantation. Leukemia 2014, 28, 1552-1555. [CrossRef]

71. Kröger, N.; Panagiota, V.; Badbaran, A.; Zabelina, T.; Triviai, I.; Cruz, M.M.A.; Shahswar, R.; Ayuk, F.; Gehlhaar, M.; Wolschke, C.; et al. Impact of Molecular Genetics on Outcome in Myelofibrosis Patients after Allogeneic Stem Cell Transplantation. Biol. Blood Marrow Transplant. 2017, 23, 1095-1101. [CrossRef] [PubMed]

72. Gagelmann, N.; Ditschkowski, M.; Bogdanov, R.; Bredin, S.; Robin, M.; Cassinat, B.; Shahswar, R.; Thol, F.; Heuser, M.; Socié, G.; et al. Comprehensive clinical-molecular transplant scoring system for myelofibrosis undergoing stem cell transplantation. Blood 2019, 133, 2233-2242. [CrossRef] [PubMed]

73. Kröger, N.; Badbaran, A.; Holler, E.; Hahn, J.; Kobbe, G.; Bornhäuser, M.; Reiter, A.; Zabelina, T.; Zander, A.R.; Fehse, B. Monitoring of the JAK2-V617F mutation by highly sensitive quantitative real-time PCR after allogeneic stem cell transplantation in patients with myelofibrosis. Blood 2006, 109, 1316-1321. [CrossRef] [PubMed] 
74. Alchalby, H.; Badbaran, A.; Bock, O.; Fehse, B.; Bacher, U.; Zander, A.R.; Kröger, N. Screening and monitoring of MPL W515L mutation with real-time PCR in patients with myelofibrosis undergoing allogeneic-SCT. Bone Marrow Transplant. 2010, 45, 1404-1407. [CrossRef] [PubMed]

75. Rumi, E.; Passamonti, F.; Arcaini, L.; Bernasconi, P.; Elena, C.; Pietra, D.; Brisci, A.; Arbustini, E.; Cazzola, M.; Lazzarino, M. Molecular remission after allo-SCT in a patient with post-essential thrombocythemia myelofibrosis carrying the MPL (W515A) mutation. Bone Marrow Transplant. 2009, 45, 798-800. [CrossRef]

76. Wolschke, C.; Badbaran, A.; Zabelina, T.; Christopeit, M.; Ayuk, F.; Triviai, I.; Zander, A.; Alchalby, H.; Bacher, U.; Fehse, B.; et al. Impact of molecular residual disease post allografting in myelofibrosis patients. Bone Marrow Transplant. 2017, 52, 1526-1529. [CrossRef]

77. Kröger, N.; Alchalby, H.; Klyuchnikov, E.; Badbaran, A.; Hildebrandt, Y.; Ayuk, F.; Bacher, U.; Bock, O.; Kvasnicka, M.; Fehse, B.; et al. JAK2-V617F-triggered preemptive and salvage adoptive immunotherapy with donor-lymphocyte infusion in patients with myelofibrosis after allogeneic stem cell transplantation. Blood 2009, 113, 1866-1868. [CrossRef]

78. Larsen, T.S.; Christensen, J.H.; Hasselbalch, H.C.; Pallisgaard, N. The JAK2 V617F mutation involves Band T-lymphocyte lineages in a subgroup of patients with Philadelphia-chromosome negative chronic myeloproliferative disorders. Br. J. Haematol. 2007, 136, 745-751. [CrossRef]

79. Jovanovic, J.V.; Ivey, A.; Vannucchi, A.M.; Lippert, E.; Leibundgut, E.O.; Cassinat, B.; Pallisgaard, N.; Maroc, N.; Hermouet, S.; Nickless, G.; et al. Establishing optimal quantitative-polymerase chain reaction assays for routine diagnosis and tracking of minimal residual disease in JAK2-V617F-associated myeloproliferative neoplasms: A joint European LeukemiaNet/MPN\&MPNr-EuroNet (COST action BM0902) study. Leukemia 2013, 27, 2032-2039.

80. Asp, J.; Skov, V.; Bellosillo, B.; Kristensen, T.; Lippert, E.; Dicker, F.; Schwarz, J.; Wojtaszewska, M.; Palmqvist, L.; Akiki, S.; et al. International external quality assurance of JAK2 V617F quantification. Ann. Hematol. 2018, 98, 1111-1118. [CrossRef]

81. Kjær, L.; Cordua, S.; Holmström, M.O.; Thomassen, M.; Kruse, T.; Pallisgaard, N.; Larsen, T.S.; De Stricker, K.; Skov, V.; Hasselbalch, H.C. Differential Dynamics of CALR Mutant Allele Burden in Myeloproliferative Neoplasms during Interferon Alfa Treatment. PLoS ONE 2016, 11, e0165336. [CrossRef] [PubMed]

82. Mansier, O.; Migeon, M.; Saint-Lézer, A.; James, C.; Verger, E.; Robin, M.; Socié, G.; Bidet, A.; Mahon, F.-X.; Cassinat, B.; et al. Quantification of the Mutant CALR Allelic Burden by Digital PCR. J. Mol. Diagn. 2016, 18, 68-74. [CrossRef] [PubMed]

83. Cordua, S.; Kjær, L.; Skov, V.; Pallisgaard, N.; Hasselbalch, H.C.; Ellervik, C. Prevalence and phenotypes of JAK2 V617F and calreticulin mutations in a Danish general population. Blood 2019, 134, 469-479. [CrossRef] [PubMed]

84. Guglielmelli, P.; Pietra, D.; Pane, F.; Pancrazzi, A.; Cazzola, M.; Vannucchi, A.M.; Tura, S.; Barosi, G. Recommendations for molecular testing in classical Ph1-neg myeloproliferative disorders-A consensus project of the Italian Society of Hematology. Leuk. Res. 2017, 58, 63-72. [CrossRef]

Publisher's Note: MDPI stays neutral with regard to jurisdictional claims in published maps and institutional affiliations.

(C) 2020 by the authors. Licensee MDPI, Basel, Switzerland. This article is an open access article distributed under the terms and conditions of the Creative Commons Attribution (CC BY) license (http://creativecommons.org/licenses/by/4.0/). 